\title{
Circular Natural Geoforms, Sierras Pampeanas, Argentina
}

\author{
Adolfo Antonio Gutiérrez, Ricardo Mon, Clara Eugenia Cisterna \\ Universidad Nacional de Tucumán, Tucumán, Argentina \\ Email: gutierrez.aa@hotmail.com, ricardomon@arnet.com.ar, claracisterna@hotmail.com
}

How to cite this paper: Gutiérrez, A.A., Mon, R. and Cisterna, C.E. (2017) Circular Natural Geoforms, Sierras Pampeanas, Argentina. Open Journal of Geology, 7, 1303-1317. https://doi.org/10.4236/ojg.2017.79086

Received: July 11, 2017

Accepted: September 4, 2017

Published: September 7, 2017

Copyright $\odot 2017$ by authors and Scientific Research Publishing Inc. This work is licensed under the Creative Commons Attribution International License (CC BY 4.0).

http://creativecommons.org/licenses/by/4.0/

\begin{abstract}
We describe two circular morphological features representing depressed areas. This preliminary work is based on visual interpretations from Landsat ETM satellite images and SRTM Radar scans. The two geoforms are located at the north of the Sierras Pampeanas in Argentina. The La Ciénaga circular indentation is $15 \mathrm{~km}$ in diameter and Las Cejas is $34 \mathrm{~km}$ in diameter. Until now rings of these characteristics, magnitudes and diameters are unknown and unheard of in Argentina.
\end{abstract}

\section{Keywords}

Impact Structures, Meteorites, Geoforms

\section{Introduction}

In the northern Sierras Pampeanas of Argentina we identified two circular natural geoforms for which we do not have any evidence to elucidate a process that gave rise to them (Figure 1). The $15 \mathrm{~km}$ wide La Ciénaga geoform is in the east of the Sierra de Fiambalá in the province of Catamarca $\left(27^{\circ} 25^{\prime} \mathrm{S}-67^{\circ} \mathrm{W}\right)$ and the $34 \mathrm{~km}$ wide Las Cejas geoform is located to the north of Dorsal Mujer Muerta on the border between the provinces of Tucuman and Santiago del Estero (26 50'S $\left.64^{\circ} 45^{\prime} \mathrm{W}\right)$.

The La Ciénaga geoform was identified from Landsat ETM imagery and the Las Cejas geoform on a Shuttle Radar Topographic Mission (SRTM) image. The following topographic maps were also used: 1:250,000 - 2766-II San Miguel de Tucuman and 2766-III Belen [1] [2], 1:200,000 Hojas Geológicas, 12c Laguna Helada [3], 12d Capillitas [4], and 1:250,000 - 2766-IV Concepción [5].

In nature, there are morphological features produced by processes or natural phenomena and whose geoforms, by themselves, allow to identify the process 


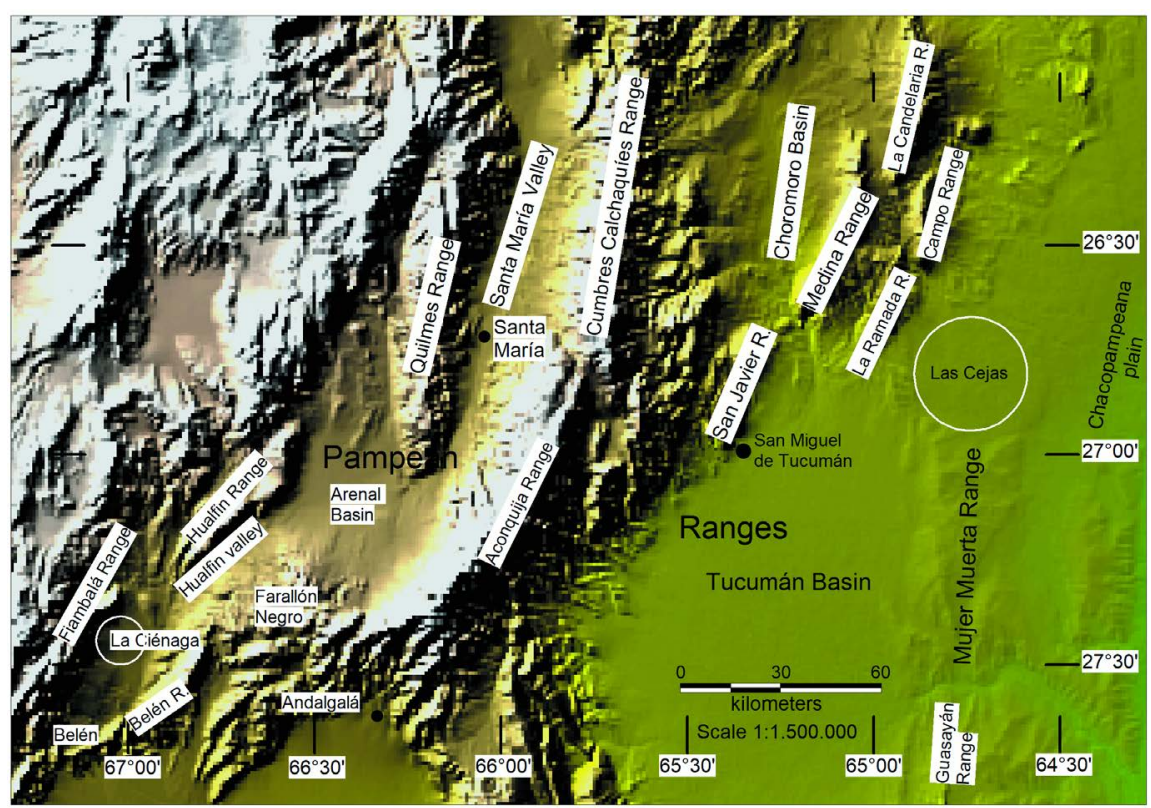

Figure 1. Regional SRTM radar image showing the location of the La Ciénaga and Las Cejas geoforms. It indicates the most important cities, the mountain ranges, and the largest basins.

that generated them. For example, alluvial fans, glacier circuses, moraines, river basins, curved structures, elliptic structures, volcanic cones, volcanic caldera, impact structures, karst geoforms, etc. (e.g., [6]-[12]). The importance to study these geoforms lies in being able to understand the processes that formed them, abundance, geographical location, etc., in order to prevent and minimize natural risks.

These two structures are not associated with volcanic rocks, limestone, tectonic processes, glaciers, etc., with which we could link their origin; thus, it was thought that they could represent impact structures. Circular geoforms such as those studied in this work, are important not only for geomorphological analysis, because they could be associated with impact cratering, but also as a tool for analysis of the effects that the impact of large objects could produce and cause to our climate and biosphere in the affected area.

According to [13], an object of $750 \mathrm{~m}$ width can generate a geoform of $15 \mathrm{~km}$ diameter, which would be sufficient to produce an atmospheric explosion over the impact site, reducing solar radiation, causing temperature distortion and injecting of dust into the stratosphere, with a residence time of $1 \mathrm{Ma}$, and if the target composition was right, inject 5 times more sulphur than the current content in the atmosphere and thereby destroying the ozone layer. To generate a geological landform of $34 \mathrm{~km}$ in diameter, it would require an object of $1700 \mathrm{~m}$ width, causing a much greater impact, considering the impact of an object only $50 \mathrm{~m}$ wide that produces a crater of $1 \mathrm{~km}$ in diameter could obliterate an area of several hundred $\mathrm{km}^{2}$ around the impact site [14].

The impact structure Araguainha (Brazil) of $40 \mathrm{~km}$ in diameter [15], was dated in $246 \mathrm{Ma}(40 \mathrm{Ar} / 39 \mathrm{Ar})$ [16]. It is a complex crater that was eroded; its 
central part rises about $150 \mathrm{~m}$ with respect to the surrounding surface, marked by rings of about $8 \mathrm{~km}$ in diameter and an internal elliptical depression of about 3 to $4.5 \mathrm{~km}[16]$.

Argentina has been alleged to have seventy-four meteorite impacts and seven other pseudo-meteorite impact sites [17] [18] [19]. In the strewn field of the Campo del Cielo meteorite in Chaco, 20 small craters are located within an area of $15 \mathrm{~km}$ length [20] [21], and the structures at Rio Cuarto (Cordoba) consist of elongated depressions that stretch over $40 \mathrm{~km}$ [22]. These meteorite impacts are arranged into five bands of NNE strike with a gap in the Santa Rosa region between $35^{\circ}$ and $37^{\circ} \mathrm{S}$ and another in the Río Gallegos region (Figure 2). We only know the age of 27 meteorite fall. The oldest are Luján in the province of Buenos Aires (50,000 - 20,000 years) and Campo del Cielo in the province of Chaco (4000 \pm 80 years, determined by radiocarbon) [19] [23]-[43]. The age of the other meteorite fall is between 1879 and 2008 (Table 1).

Table 1. Age of meteorites fall in Argentina. WL: west latitude. SL: south latitude.

\begin{tabular}{|c|c|c|c|c|c|}
\hline WL & SL & Meteorite & Province & Location & $\begin{array}{c}\text { Age } \\
\text { (years) }\end{array}$ \\
\hline$-58^{\circ} 20^{\prime}$ & $-31^{\circ} 55^{\prime}$ & Berduc & Entre Ríos & & 2008 \\
\hline$-68^{\circ} 29^{\prime}$ & $-31^{\circ} 32^{\prime}$ & Santa Lucía & San Juan & Villa Manuelita & 2008 \\
\hline$-68^{\circ} 05^{\prime}$ & $-29^{\circ} 55^{\prime}$ & Talampaya & La Rioja & & 1995 \\
\hline$-65^{\circ} 06^{\prime}$ & $-23^{\circ} 07^{\prime}$ & Palca de Aparzo & Jujuy & & 1988 \\
\hline$-58^{\circ} 06^{\prime}$ & $-31^{\circ} 16^{\prime}$ & La Criolla & Entre Ríos & La Criolla & 1985 \\
\hline$-64^{\circ} 12^{\prime}$ & $-30^{\circ} 26^{\prime}$ & Deán Funes & Córdoba & Deán Funes & 1977 \\
\hline$-65^{\circ} 27^{\prime}$ & $-26^{\circ} 40^{\prime}$ & Raco & Tucumán & Raco & 1957 \\
\hline$-60^{\circ} 28^{\prime}$ & $-31^{\circ} 53^{\prime}$ & Distrito Quebracho & Entre Ríos & Paraná & 1957 \\
\hline$-66^{\circ} 00^{\prime}$ & $-33^{\circ} 00^{\prime}$ & Árbol Solo & San Luis & Socoscora & 1954 \\
\hline$-67^{\circ} 30^{\prime}$ & $-27^{\circ} 15^{\prime}$ & Medanitos & Catamarca & Tinogasta & 1953 \\
\hline$-60^{\circ} 40^{\prime}$ & $-31^{\circ} 25^{\prime}$ & Arroyo Aguiar & Santa Fe & & 1950 \\
\hline$-66^{\circ} 09^{\prime}$ & $-44^{\circ} 07^{\prime}$ & Uzcudún & Chubut & Ameghino & 1948 \\
\hline$-64^{\circ} 52^{\prime}$ & $-32^{\circ} 20^{\prime}$ & Belville & Córdoba & Unión & 1937 \\
\hline$-64^{\circ} 33^{\prime}$ & $-30^{\circ} 53^{\prime}$ & Capilla del Monte & Córdoba & Capilla del Monte & 1934 \\
\hline$-58^{\circ} 03^{\prime}$ & $-30^{\circ} 47^{\prime}$ & Chajarí & Entre Ríos & Federación & 1933 \\
\hline$-58^{\circ} 37^{\prime}$ & $-33^{\circ} 00^{\prime}$ & Gualeguaychú & Entre Ríos & La Constancia & 1932 \\
\hline$-63^{\circ} 14^{\prime}$ & $-28^{\circ} 56^{\prime}$ & Malotas & Santiago del Estero & Salavina & 1931 \\
\hline$-65^{\circ} 14^{\prime}$ & $-31^{\circ} 36^{\prime}$ & Aguada & Córdoba & Pocho & 1930 \\
\hline$-57^{\circ} 57^{\prime}$ & $-31^{\circ} 11^{\prime}$ & Isthilart & Entre Ríos & Federación & 1928 \\
\hline$-65^{\circ} 17^{\prime}$ & $-32^{\circ} 45^{\prime}$ & Renca & San Luís & & 1925 \\
\hline$-61^{\circ} 42^{\prime}$ & $-33^{\circ} 54^{\prime}$ & Santa Isabel & Santa Fe & & 1924 \\
\hline$-61^{\circ} 32^{\prime}$ & $-37^{\circ} 20^{\prime}$ & La Colina & Buenos Aires & General La Madrid & 1924 \\
\hline$-64^{\circ} 57^{\prime}$ & $-33^{\circ} 10^{\prime}$ & Achiras & Córdoba & Río cuarto & 1902 \\
\hline$-59^{\circ} 50^{\prime}$ & $-32^{\circ} 22^{\prime}$ & Nogoyá & Entre Ríos & & 1879 \\
\hline$-60^{\circ} 35^{\prime}$ & $-27^{\circ} 28^{\prime}$ & Campo del Cielo & Chaco & & $4000 \pm 80$ \\
\hline$-59^{\circ} 22^{\prime}$ & $-34^{\circ} 40^{\prime}$ & Luján & Buenos Aires & Luján & $\begin{array}{c}50,000- \\
20,000\end{array}$ \\
\hline
\end{tabular}




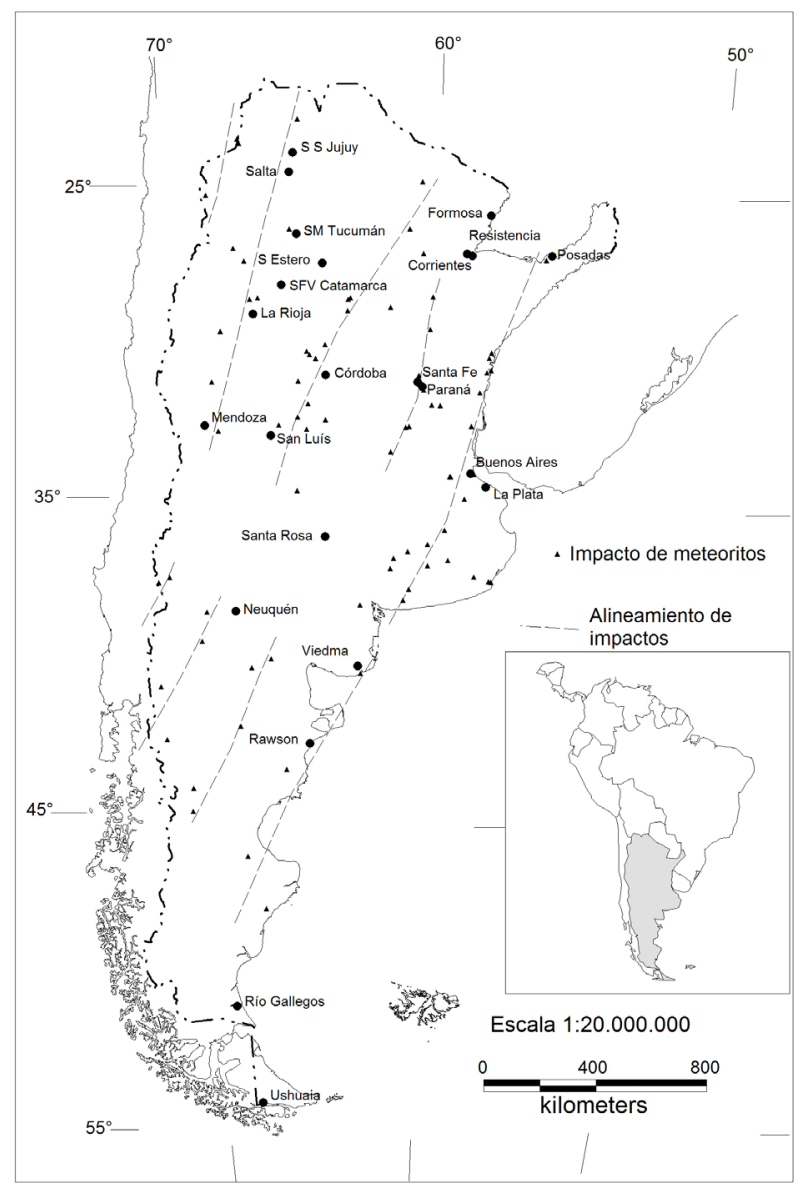

Figure 2. Map of Argentina with the location of meteorite falls. With the dashed lines indicating that these sites lie in five bands with NNE strike. In the central and south area (Santa Rosa and Rio Gallegos) there are no records of meteorite falls.

\section{Results}

\subsection{The La Ciénaga Geoform (15 km in Diameter)}

The circular feature of La Ciénaga is located in the province of Catamarca, inside an intermountain depression situated between the Sierra de Fiambalá to the west and the Sierra de Belén to the east and south. To the north, a set of lower elevations separate the circular geoform from the Hualfín valley. This valley is limited to the NW by the Sierra de Hualfín and to the SE by the Farallon Negro Volcanic Complex; toward the NE it is connected with the Campo del Arenal (Figure 1).

La Ciénaga, situated southeast of the geoform, is the most important locality in the area. The Belén River flows to SW along the eastern edge of the circular feature; it is the main collector of water in the area and the Loconte River and smaller channels flow down towards it from the mountains located to the west (Figure 3).

\subsubsection{General Geological Characteristics}

The oldest rocks are represented by metamorphic rocks of the Loma Corral Formation of Upper Precambrian-Lower Cambrian age that was intruded by 


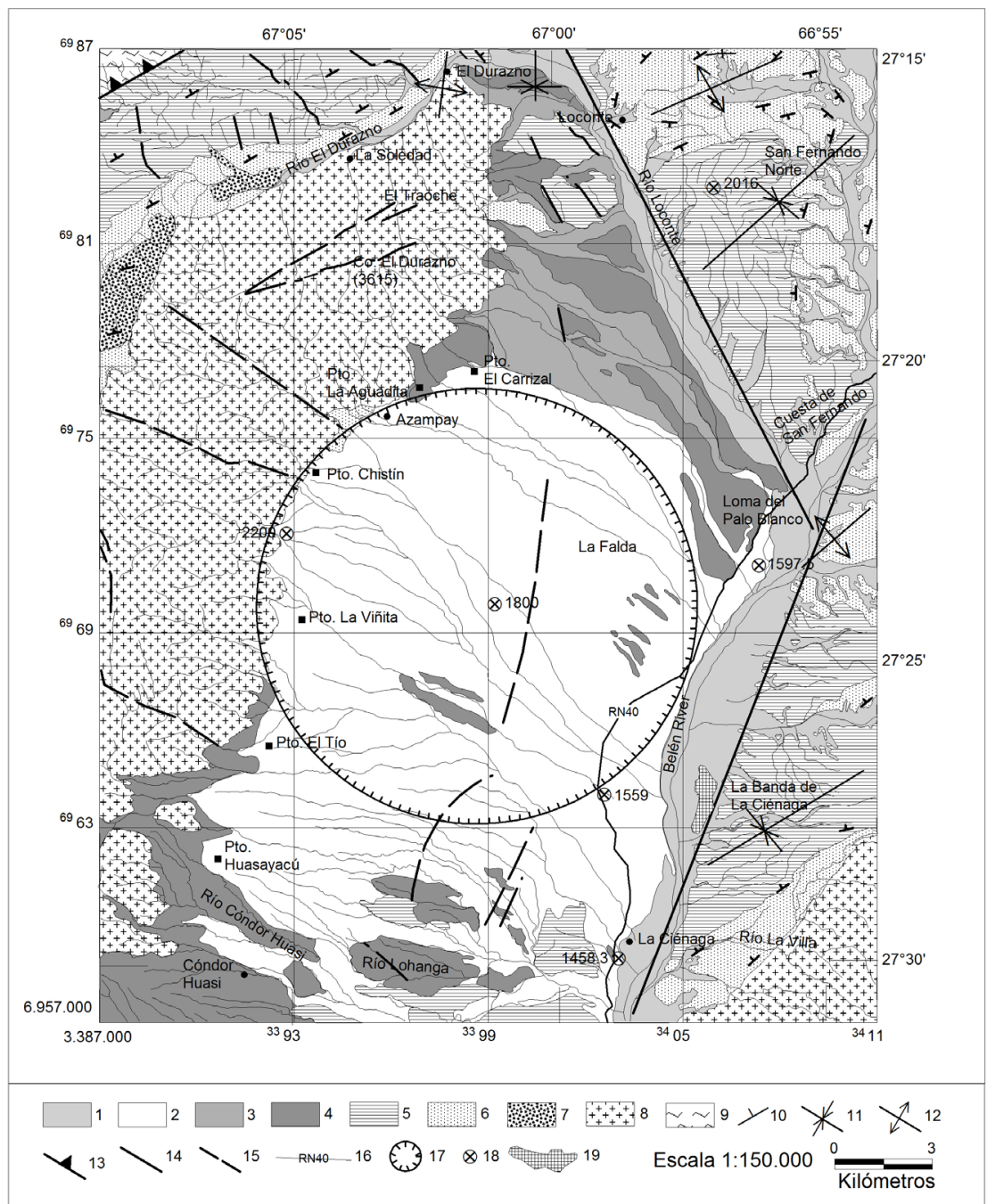

Figure 3. Geological map of the La Ciénaga geoform. 1: Fluvial-wind deposits (Q). 2, 3 and 4: Alluvial fans deposits (Q). 5: El Cajon Formation (El Bolson Group) (Ts). 6: El Aspero Formation (El Bolson Group) (Ts). 7: El Morterito Formation (El Bolson Group) (Ts). 8: Chango Real Formation (Pz). 9: Loma Corral Formation (Pc-C). 10: Stratification. 11: Syncline. 12: Anticline. 13: Reverse fault. 14: Lineament. 15: Supposed fault. 16: National Route 40. 17: La Ciénaga geoform. 18: masl. 19: Acreage land area.

granitic rocks of the Chango Real Formation in the Lower Palaeozoic [3]. These rocks form the core of the mountain that borders the geomorphic feature to the west; to the southeast there is a low outcrop of granitic rock that forms part of the Sierra de Belén (Figure 1 and Figure 3).

The igneous-metamorphic rocks supporting continental sediments (El Cajón and El Morterito formations) of Tertiary age belong to the El Bolsón Group. The volcanic rocks of the El Áspero Formation intrude the sequence of the El Morterito Formation and underlie the El Cajón Formation, which is also part of the El Bolsón Group [3] [4]. The El Bolsón Group has its major development in the eastern sector of the area close to the geomorphic feature; towards the northwest it overlies the igneous-metamorphic basement (Figure 3). 
The geological sequence ends with three sedimentary levels of Quaternary alluvial fans and fluvio-eolian deposits [3] (Figure 3).

The igneous-metamorphic basement of the range that ends to the west of the geomorphic feature constitutes the core of a major anticlinal fold, striking NNE, which dips to the north (Figure 3). The sedimentary sequence of the El Bolsón Group that forms part of the western flank of the fold dips westward. However, the eastern flank of the fold also consisting of the sequence of the El Bolsón Group is refolded, forming anticlines and synclines. Another outstanding feature of the eastern flank of the fold is that the sedimentary-volcanic sequence is not attached to the eastern flank of the igneous-metamorphic basement core. It is separated by the intermountain depression where the geomorphic circular feature is located. Only small outcrops are seen attached to the eastern edge of the mountain range (Figure 3). All folds at the eastern edge of the intermountain depression strike NE and are cut by faults, eroded or covered by quaternary deposits (Figure 3).

The metamorphic rocks of the Loma Corral Formation overlie the El Bolsón Group sequence because of a NE reverse fault that dips to the NW [3]. NW and $\mathrm{NE}$ regional lineaments parallel to the Loconte and Belén rivers are cutting folds in the northeast and southeast areas, respectively (Figure 3). Here occur other minor lineaments that affect the entire geological sequence. In the intermountain depression, some lineaments are cutting the Quaternary deposits and Neogene sediments (Figure 3 ).

\subsubsection{Morphology of the Circular Feature}

The circular geoform is a depressed area with respect to the rest of the intermountain region; the center of the depression is at 1800 masl. The western border is higher than the eastern with a $641 \mathrm{~m}$ drop; the center is at $400 \mathrm{~m}$ lower elevation compared to western side. The intermountain area is covered by Quaternary sediments that have formed as coalescing alluvial fans with a general slope to the southeast, distributed in three terraced levels. The depression of the circular geoform is evidence by the lowering sedimentary levels morphology. To the north, the second and third level deposits are truncated by the edge of the crater and the third level continually extends to the south. With greater development, but in the center of the depressed area, the third level can be seen only in the form of islands outcrops. Later the depressed area was filled with deposits of the first level (Figure 3 and Figure 4).

The mountain range of NE strike, to the west of the study area, forms part of the Sierra de Fiambalá (Figure 1). The section that occupies the area is cut by three ESE striking lineaments. The lineament located between Azampay and Puesto Chistin marks a break in the range, to the north the range strike NE, and to the south in NS direction (Figure 1 and Figure 3). This break, coupled with the intense erosion of the eastern slope of the range has created an eastern concave shape, defining a semi-circular contour which forms the western edge of the crater (Figure 3 and Figure 4). 


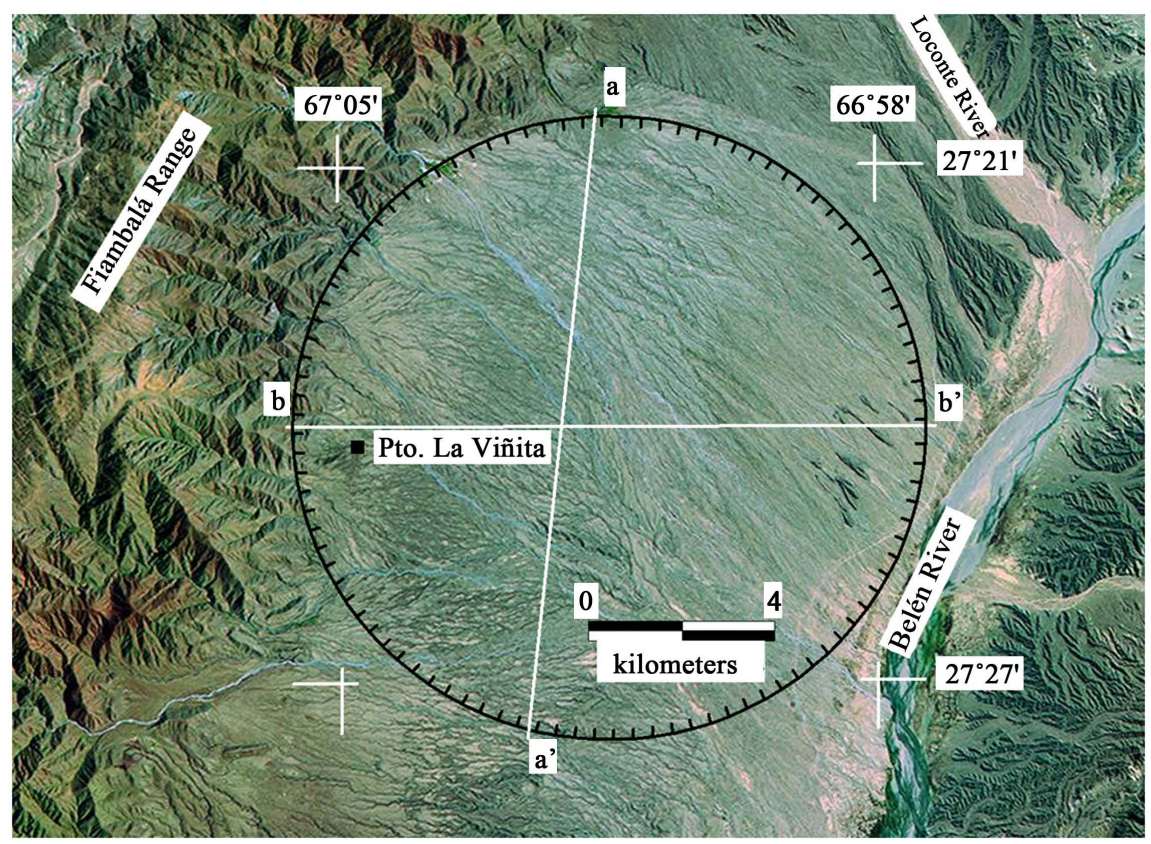

Figure 4. Schematic location of the profile lines and view of the regional morphology on a Landsat image.

The Neogene folded sequence of the El Bolsón Group is separated from the eastern flank of the range by the basin. Western reaches of these folds appear to have been cut, as if the sedimentary sequence had slipped into the depression, as the morphology presented alluvial fans in the northern sector (Figure 3 and Figure 4).

Northeast and northwest, outside the area, are the Farallón Negro and Vicuña Pampa volcanic complexes of Neogene age [44] (Figure 1). The volcanic sequence of the El Cajón Formation (El Bolsón Group) originates from the Farallón Negro Volcanic Complex [3] [4]; the circular feature appears to predate the sedimentary sequence of the El Bolson Group (Figure 3 and Figure 4). The $\mathrm{E}-\mathrm{W}$ relief of the structure has a slope of $8 \%$ and the western edge is abrupt; in this slope, surficial drainage development and consequent erosion processes have occurred (Figure 5(a)). The N-S profile highlights the concavity of the circular structure; the northern edge is higher than the southern edge and in the central area there are small elevations with quaternary sediment residues (Figure $5(\mathrm{~b}))$.

\subsection{The Las Cejas Geoform ( $34 \mathrm{~km}$ in Diameter)}

The Las Cejas geoform is located at the northern end of the Dorsal Mujer Muerta. This area forms part of a topographic high of sub-meridian strike that is 340 $\mathrm{km}$ long and $90 \mathrm{~km}$ wide and closes eastward of the Tucuman basin. To the north continue the foothills of the Sierra del Campo, to the west border the Sierra de La Ramada highlands, and to the east extend the Chaco Pampeana plains (Figure 1). The locality of Las Cejas in the southern part of the depression is the most populated and important place around (Figure 6). 


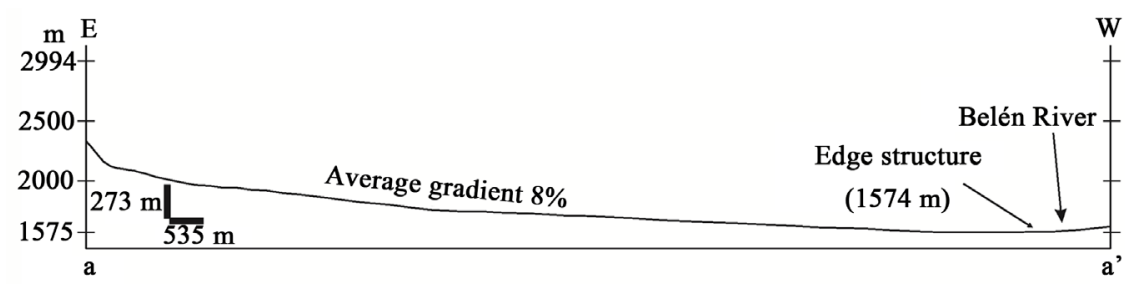

(a)

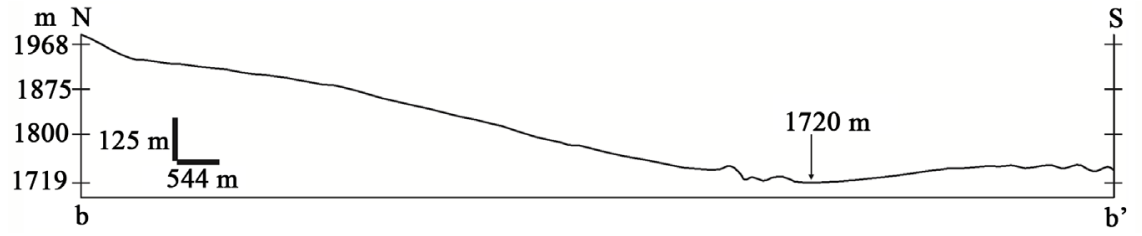

(b)

Figure 5. Profiles illustrating the general morphology of the structure. In profile (a) La Ciénaga structure, EW profile; the regional WE slope is observed; and in profile (b) La Ciénaga structure, NS profile; the cup-shaped structure with marked edges are shown.

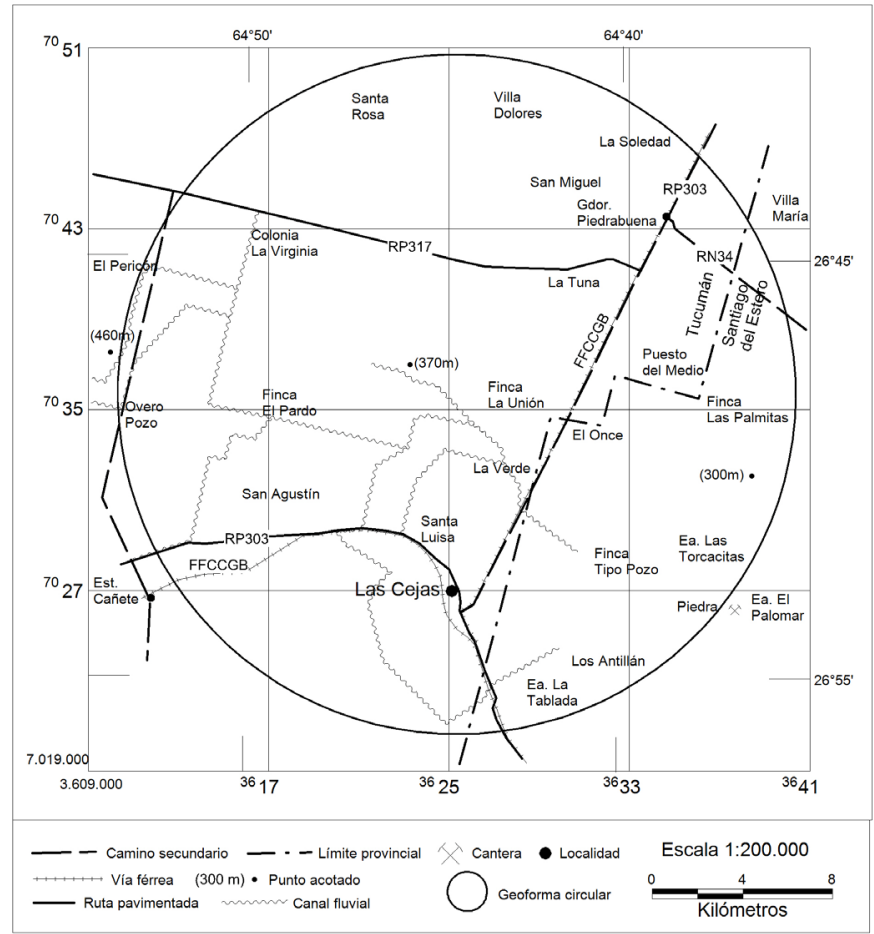

Figure 6. Planialtimetric map of the Las Cejas geoform. It indicates localities, roads, artificial drainage and the interprovincial border.

\subsubsection{General Geological Characteristics}

The area is totally cultivated, so it is impossible to perform a visual interpretation of satellite images. The Dorsal Mujer Muerta is buried, covered by Neogene and Quaternary sediments. The rocks outcrop only in the Sierra de Guasayán highlands (550 masl). The natural drainage that flowed from the Sierra de La Ramada was deactivated and replaced by artificial channels (Figure 1 and Figure 6). 
In the Sierra de Guasayán outcrop metamorphic rocks of Upper PrecambrianLower Cambrian age, intruded by granitic rocks, granodiorites and tonalities of Ordovician to Carboniferous age, which are covered by sedimentary rocks of Neogene and Quaternary age [5] (Figure 1).

To the west, in the ranges of La Ramada and Medina, there are outcrops of small bodies of intrusive subvolcanic rock of Cretaceous age [45]. However, near the circular structure, we have not identified in satellite images or in the field any, rocks, or morphologies that could be thought typical for volcanic activity (Figure 6 and Figure 7).

\subsubsection{Morphology of the Circular Feature}

The Las Cejas geoform is a semi-circular indentation of about $34 \mathrm{~km}$ diameter that seems to have obliterated the northern tip of the Dorsal Mujer Muerta. In the radar image this feature is linked to a flat morphology elongated ESE (40 $\mathrm{km}$ ), a smooth surface that contrasts with the raised, truncated edges of the ridge to the west and south, and with others of lesser height to the north and east. Its minor axis is about $32 \mathrm{~km}$ long. In topographic maps, it shows that the ground is not completely flat, with hills and depressions marking some $380 \mathrm{~m}$ of topographic gradient (Figure 7 and Figure 8).

The center of the geoform is at 370 masl; the western edge is higher than the eastern edge, with a vertical drop of $160 \mathrm{~m}$. The drop between the western edge and the central zone is $90 \mathrm{~m}$ (Figure 6 and Figure 7). The E-W relief on the

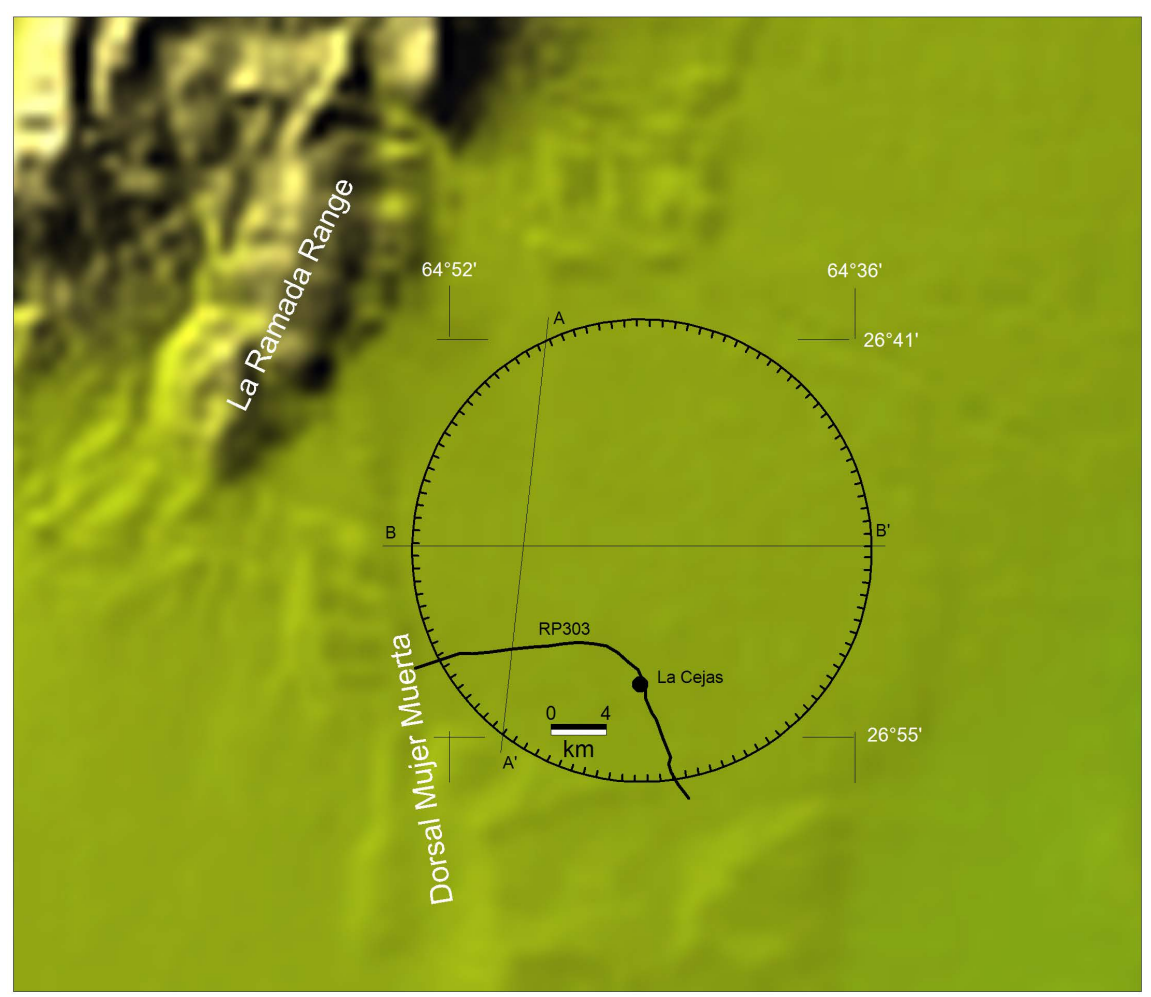

Figure 7. Schematic location of the profiles AA' and BB' lines and view of the regional morphology on a SRTM Radar image. 


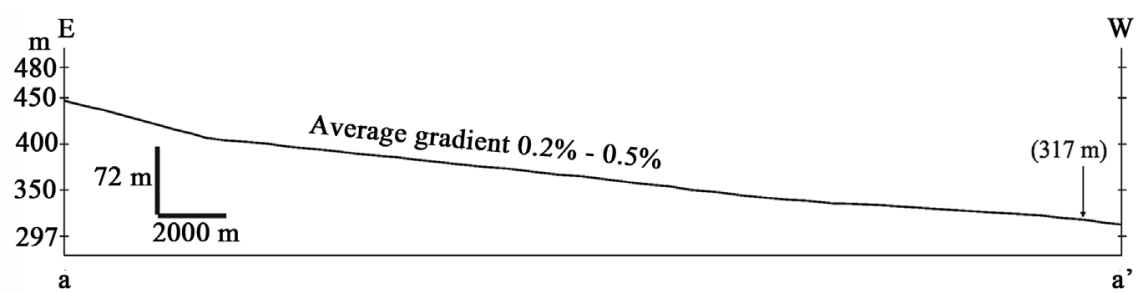

(a)

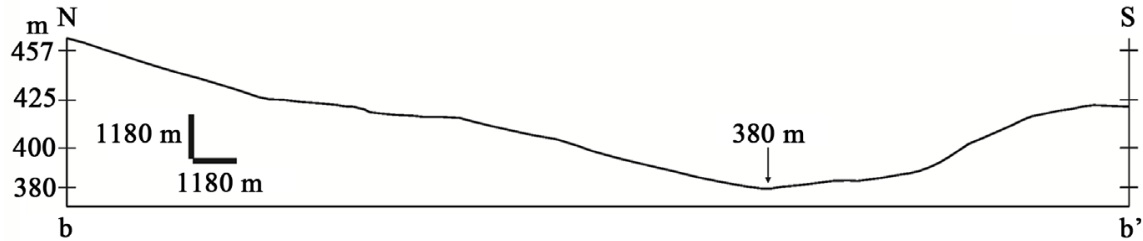

(b)

Figure 8. Profiles indicating the general morphology of the Las Cejas structure. In profile (a) Las Cejas structure, EW profile; you can see a regional slope along the W-E profile; and in profile (b) Las Cejas structure, NS profile; the cup-shaped structure with marked edges is.

western edge has a slope of $0.9 \%$ that then decreases eastward to $0.2 \%$ to $0.5 \%$ (Figure 8(a)). In Figure 8(b) the concavity of the structure is best appreciated and shows the abrupt edge of the south wall.

It is possible that the circular feature was formed prior to the deposition of Neogene sedimentary rocks.

\section{Discussion}

No other circular structures of such diameters are known in Argentina. Of the seventy-four cases of meteorite falls and other seven pseudo-meteorites mentioned in the literature, only two are special cases of large meteorites (Campo del Cielo in Chaco and Rio Cuarto in Córdoba). The meteorite falls in Argentina are aligned in a NNE strike, distributed from north to south, but in the central area (Santa Rosa) and to the south (Río Gallegos) there is no evidence of meteorite fall. The oldest meteorite falls (Lujan and Campo del Cielo) are dated between 50,000 20,000 years and $4000 \pm 80$ years, respectively; the remaining meteorite falls age between the years 1879 and 2008 (Figure 1 and Figure 2; Table 1).

An impact structure can be simple or complex in its construction [46]. A simple crater on Earth is small, less than $4 \mathrm{~km}$ in diameter, with a bowl-shaped geometry and a raised rim. A complex structure has diameters $>4 \mathrm{~km}$ and on Earth the largest known such structure was ca 250 - $300 \mathrm{~km}$ wide, prior to erosion (Vredefort, South Africa) [47]. With the exception of very low-angle impact events, the resulting crater structures are invariably circular. According to impact magnitude and target composition, the interiors of complex impact structures will have a central peak (stratigraphic uplift), peak ring, or multiple ring structures.

The La Ciénaga structure with a $15 \mathrm{~km}$ diameter and the Las Cejas structure 
with a $34 \mathrm{~km}$ diameter have circular shapes and in plan views on satellite images show a flat morphology with marked edges (Figure 4 and Figure 7). Being seen in a profile, both structures have a central depression of about $2.7 \mathrm{~km}$ (La Ciénaga) and $12 \mathrm{~km}$ (Las Cejas); the general slope towards the $\mathrm{E}$ strike is smooth (Figure 5(a) and Figure 8(a)) however in the N-S profile it reflects a concave cup-shaped morphology (Figure 5(b) and Figure 8(b)).

In Chaco, more than 20 impact craters are known from which numerous meteorite fragments were recovered; apart from Campo del Cielo other prominent craters are La Perdida, Rubin de Celiz, Gomez and Laguna Negra [18].

At $24 \mathrm{~km}$ and $83 \mathrm{~km}$ south of the Campo del Cielo meteorite strewn field, at the southeastern edge of the Lomadas de Otumpa, we identified in radar images the remains of four semi-circular and elliptical structures. These structures of 15.0, $16.5,18.0$ and $31.5 \mathrm{~km}$ in diameter occur as in showing the aftermath of an object's impact. These depressions have now become lakes, as one is called El Cisne (Figure 9). Are these geoforms impact structures related with meteorites fallen $4000 \pm 80$ years ago, in Campo del Cielo? With other age meteorites? Or are they natural erosional features? In this area, no volcanic manifestations were found which could be associated with these circular features.

In South America, the only known impact crater is Araguainha (Brazil) with $40 \mathrm{~km}$ in diameter [16]. The La Ciénaga and Las Cejas structures do not have the

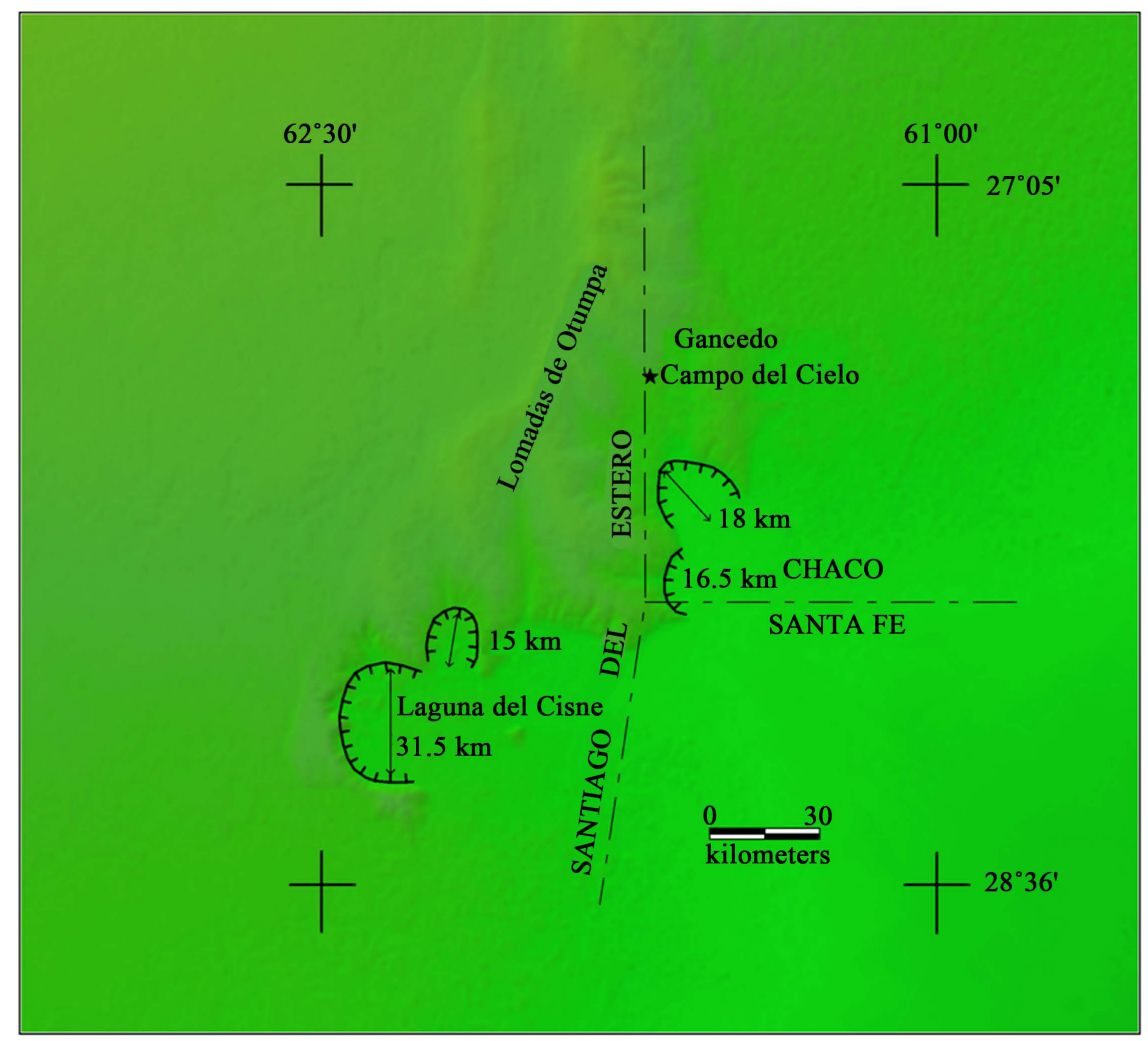

Figure 9. Four semi-circular structures located in the Lomadas de Otumpa area south of the Campo del Cielo meteorite strewn field. These four structures represent lakes or small bodies of water. 
morphology that characterizes Araguainha crater impact, perhaps because they are covered by Neogene and Quaternary sediments that bury those characteristic features. However, the erosion of these sediments marks the outer rings of structures, and can be observed in satellite images. They are not related to volcanic structures because there are no lava flows associated with them nor have there been volcanic rocks identified near the structures nor on satellite images nor during field work.

La Ciénaga and Las Cejas structures are geomorphic features that need to be investigated in more detail to elucidate their origin and age. A relation with meteorite impact or other natural events must be elucidated, considering that:

1) They are circular, slightly elongated geoforms that are well defined.

2) No impact structures have been identified in Argentina yet.

3) The sediments that cover them appear to have slumped inward towards their rings and the erosion permits you to see the circular morphology of the structures.

4) Both structures appear to have originated before deposition of the Neogene sediments.

5) Nearby in the La Ciénaga area there are volcanic manifestations (Farallón Negro and Vicuña Pampa) but the circular structure does not seem to be related to a volcanic event.

6) In the Las Cejas area, no volcanic manifestations have been found that could be associated with the circular structure.

7) The impact of large objects would produce catastrophic effects on the climate and biosphere. To generate an impact structure of $15 \mathrm{~km}$ in diameter (La Ciénaga) it would require an object of $750 \mathrm{~m}$ wide and to generate a structure of $34 \mathrm{~km}$ (Las Cejas) an object of $1700 \mathrm{~m}$ wide, at an average velocity of $25 \mathrm{~km} / \mathrm{s}$ [48]. The impact of objects with these dimensions can produce an atmospheric explosion over the impact site, reducing solar radiation, temperature distortion and injection into the stratosphere, for periods of up to $1 \mathrm{Ma}$, five times more sulphur that the current content, destroying the ozone layer [13] [14].

\section{Acknowledgements}

This work was realized with funds of projects financed by the CIUNT, National University of Tucuman, Argentina. Our thanks to Dr Uwe Reimold for the critical reading of the manuscript, suggestions and valuable contribution.

\section{References}

[1] Instituto Geográfico Militar (1991a) Carta Topográfica 1:250.000 2766-II San Miguel de Tucumán (provincias de Tucumán, Salta, Santiago del Estero y Catamarca). Buenos Aires, Argentina.

[2] Instituto Geográfico Militar (1991b) Carta Topográfica 1:250.000 2766-III Belén (provincias de Catamarca y Tucumán). Buenos Aires, Argentina.

[3] Ruíz Huidobro, O.J. (1975) Carta Geológico-Económica Laguna Helada-12c, provincia de Catamarca, escala 1:200.000. Ministerio de Economía, Servicio Nacional 
Minero Geológico, 146, 68 p.

[4] González Bonorino, F. (1947) Carta Geológico-Económica Capillitas-12d, provincia de Catamarca, escala 1:200.000. Ministerio de Economía, Dirección General de Minas y Geología, 65, 72 p.

[5] DalMolin, C.N., Fernández, D. and Escosteguy, L. (2003) Hoja Geológica 2766-IV Concepción, escala 1:250.000 (provincias de Tucumán, Catamarca y Santiago del Estero). Servicio Geológico Minero Argentino, 342, 41 p.

[6] Summerfield, M.A. (1991) Global Geomorphology: An Introduction to the Study of Landforms. Pearson, Prentice Hall, England, 537 pp.

[7] French, B.M. (1998) Traces of Catastrophe: A Handbook of Shock-Metamorphic Effects in Terrestrial Meteorite Impact Structures. Lunar and Planetary Institute, Houston, 120 pp.

[8] Gutiérrez, A.A. (1999) Tectonic Geomorphology of the Ambato Block (Northwestern Pampeanas Mountain Ranges, Argentina). Fourth International Symposium on Andean Geodynamics, 1, 307-310.

[9] Tsikalas, F. (2005) Mjølnir Crater as a Result of Oblique Impact: Asymmetry Evidence Constrains Impact Direction and Angle. In: Koeberl, C. and Henkel, H., Eds., Impact Tectonics, Springer, Berlin, 285-306.

https://doi.org/10.1007/3-540-27548-7_10

[10] Cunningham, W.D. (2007) Structural and Topographic Characteristics of Restraining Bend Mountain Ranges of the Altai, Gobi Altai and Easternmost Tien Shan. In: Cunningham, W.D. and Mann, P., Eds., Tectonics of Strike-Slip Restraining and Releasing Bends, Geological Society Special Publication, London, 219-238. https://doi.org/10.1144/SP290.7

[11] Gutiérrez, A.A. and Mon, R. (2008) Macroindicadores cinemáticos en el Bloque Ambato, provincias de Tucumán y Catamarca. Revista de la Asociación Geológica Argentina, 63, 24-28.

[12] Zampieri, D., Gutiérrez, A.A., Massironi, M. and Mon, R. (2012) Reconciling Opposite Strike-Slip Kinematics in the Transpressional Belt of the Sierra Pampeanas (Argentina). European Geosciences Union General Assembly, Viena, 2 p.

[13] Chapman, C.R. and Morrison, D. (1989) Cosmic Catastrophes. Plenum Press, New York, 302 p. https://doi.org/10.1007/978-1-4899-6553-0

[14] Kring, D.A. (1997) Air Blast Produced by the Meteor Crater Impact Event and a Reconstruction of the Affected Environment. Meteoritics \& Planetary Science, 32, 517-530. https://doi.org/10.1111/j.1945-5100.1997.tb01297.x

[15] Dietz, R.S. and French, B.M. (1973) Probable Astroblemes in Brazil. Nature, 244, 561f. https://doi.org/10.1038/244561a0

[16] Engelhardt, W.V., Matthai, S.K. and Walzebuck, J. (1992) Araguainha Impact Crater, Brazil. I. The Interior Part of the Uplift. Meteoritics, 27, 442-457.

[17] Rocca, M.C.L. (2003) El Cráter en la Meseta de la Barda Negra, Neuquén: Un potencial nuevo impacto de meteorito en Patagonia, Argentina. Cambridge Conference Network, Vol. 116, 7 p.

[18] Acevedo, R.D., Valín-Alberdi, M.L. and Villar, L.M. (2002) Hallazgo del mineral fosfuro de Níquel en una octahedrita IAB de Rubín de Celis (Campo del Cielo, Argentina). 1 Congreso Ibérico de Meteoritos y Geología Planetaria, Resúmenes, Museo de las Ciencias de Castilla-La Mancha, Cuenca.

[19] Acevedo, R.D. and Roca, M.C.L. (2008) Catálogo de los meteoritos hallados en territorio argentino. Actas del 17 Congreso Geológico Argentino, Vol. 3, 1317-1318, 
San Salvador de Jujuy.

[20] Cassidy, W.A. and Wright, S.P. (2003) Small Impact Craters in Argentine Loess: A Step up from Modeling Experiments.Workshop on Impact Cratering, 8004 p.

[21] Bocanera, R. (2006) Algunas observaciones sobre meteoritos y meteoros. Petrotecnia, 80-88.

[22] Bland, P.A., De Souza, F.C.R., Hough, R.M., Pierazzo, E., Coniglio, J., Pinotti, L., Jull, A.J.T. and Evers, V. (2001) The Río Cuarto Crater Field Revisited: Remote Sensing Imagery Analysis and New Field Observations. 64th Annual Meteoritical Society Meeting, $5319 \mathrm{p}$.

[23] Ameghino, F. (1914) Aerolito fósil. Obras completas y Correspondencia Científica: Tomo, 2, 276-279.

[24] Herrero Ducloux, E. (1914) Nota sobre el meteorito carbonoso de Nogoyá. AnalesMuseo Nacional de Historia Natural, Buenos Aires, 26, Mineralogía, Petrografía, 3, 99-116.

[25] Herrero Ducloux, E. (1925) Nota sobre el meteorito de La Colina. Anales MuseoNacional de Historia Natural, Buenos Aires, 33, 287-295.

[26] Herrero Ducloux, E. (1926) Nota sobre el meteorito de Santa Isabel. Revista Facultad de Ciencias Químicas La Plata, 4, 23-29.

[27] Herrero Ducloux, E. (1940) Nota sobre el meteorito de Gualeguaychú. Anales Museo Argentino de Ciencias Naturales. Buenos Aires. 40, Mineralogía. Petrografía, 14, 123-127.

[28] Pastore, F. (1925) Aerolito de La Colina. Anales Museo Nacional de Historia Natural. Buenos Aires 33, Mineralog., Petrogr. Vol. 6, 297-306.

[29] Herrero Ducloux, E. and Pastore, F. (1929) El meteorito de Renca. Revista Facultad Química Farmacia La Plata, 5, 111-120.

[30] Herrero Ducloux, E. and Pastore, F. (1930) El Meteorito de Ishtilart. Anales Museo Argentino de Ciencias Naturales. Buenos Aires 36, Mineralogía. Petrografía, 9, 313-330.

[31] Olsacher, J. (1951) Condrita de Achiras. Boletín Academia Nacional de Ciencias de Córdoba, 39, 261-267.

[32] Olsacher, J. (1951) Condrita de Quebrada de la Aguada. Boletín Academia Nacional de Ciencias de Córdoba, 39, 268-273.

[33] The Permanent Commission on Meteorites of the International Geological Congress (1961) Meteorites Not Included in the Prior-Hey Catalogue of Meteorites, 1953. The Meteoritical Bulletin, 21, 1-3.

[34] The Permanent Commission on Meteorites of the International Geological Congress (1962) Meteorites Not Included in the Prior-Hey Catalogue of Meteorites, 1953. The Meteoritical Bulletin, 24, 1-6.

[35] The Permanent Commission on Meteorites of the International Geological Congress (1962) Meteorites Not Included in the Prior-Hey Catalogue of Meteorites, 1953. The Meteoritical Bulletin, 25, 1-3.

[36] The Permanent Commission on Meteorites of the International Geological Congress (1964) Discovery of Arbol Solo Stony Meteorite, Argentina. The Meteoritical Bulletin, 32, 1-6.

[37] Teruggi, M.E. (1968) El Meteorito condriticoChajari. Revista del Museo de La Plata, 6, $21 \mathrm{p}$.

[38] Giacomelli, L.O. (1969) Guía de Meteoritos de la Argentina. Revista Museo 
Argentino de Ciencias Naturales, Geología, 7, 1.

[39] Graham, A.L. (1986) Fall of the La Criolla, Stony, Argentina. The Meteoritical Bulletin, 64, 310 .

[40] Wlotzka, F. (1994) The Meteoritical Bulletin, No. 77. Meteoritics, 29, 891-897. https://doi.org/10.1111/j.1945-5100.1994.tb01104.x

[41] Grossman, J.N. (1998) The Meteoritical Bulletin, No. 82. Meteoritics and Planetary Science, 33, A221-A239. https://doi.org/10.1111/j.1945-5100.1998.tb01336.x

[42] Grossman, J.N. (1999) The Meteoritical Bulletin, No. 83. Meteoritics and Planetary Science, 34, A169-A186. https://doi.org/10.1111/j.1945-5100.1999.tb01762.x

[43] Weisberg, M.K., Smith, C., Benedix, G., Herd, C.D.K., Righter, K., Haack, H., Yamaguchi, A., ChennaouiAoudjehane, H. and Grossman, J.F. (2010) The Meteoritical Bulletin, No. 97. Meteoritics and Planetary Science, 45, 449-493. https://doi.org/10.1111/j.1945-5100.2010.01036.x

[44] Sasso, A. and Clark, A. (1999) El Grupo Farallón Negro: Evolución magmática, hidrotermal y tectónica e implicancias para la metalogenia de cobre-oro en el retroarco andino, Catamarca. In: Zappettini, E.O., Ed., Recursos Minerales de la República Argentina, Instituto de Geología y Recursos Minerales SEGEMAR, Anales, Vol. 35, 1437-1450, Buenos Aires.

[45] Bossi, G.E. and Wampler, M. (1969) Edad del Complejo Alto de las Salinas y Formación El Cadillal según el método K-Ar. Acta Geológica Lilloana, 10, 141-160.

[46] Melosh, H.J. (1989) Impact Cratering. Oxford University Press, 245 p.

[47] Elston, W.E. (1992) Does the Bushveld-Vredefort System (South Africa) Record the Largest Known Terrestrial Impact Catastrophe? International Conference on Large Meteorite Impacts and Planetary Evolution, Canadá, 23-24.

[48] Crawford, D.A. and Schultz, P.H. (1992) Enhanced Magnetic Field Production during Oblique Hypervelocity Impacts. International Conference on Large Meteorite Impacts and Planetary Evolution, Canadá, 18-20.

Submit or recommend next manuscript to SCIRP and we will provide best service for you:

Accepting pre-submission inquiries through Email, Facebook, LinkedIn, Twitter, etc. A wide selection of journals (inclusive of 9 subjects, more than 200 journals)

Providing 24-hour high-quality service

User-friendly online submission system

Fair and swift peer-review system

Efficient typesetting and proofreading procedure

Display of the result of downloads and visits, as well as the number of cited articles

Maximum dissemination of your research work

Submit your manuscript at: http://papersubmission.scirp.org/

Or contact ojg@scirp.org 